\title{
Pengaruh Kecerahan Warna Lipstik terhadap Banyaknya Kandungan Logam Berat Timbal, Kromium, dan Kadmium yang Dianalisis Menggunakan Atomic Absorption Spectroscopy (AAS)
}

\author{
Ayuni Adinda ${ }^{1)}$, Ade Trisnawati ${ }^{2 *}$, Novia Fahmi Ayu W. ${ }^{3)}$, Mayang Restiawati ${ }^{4)}$ \\ ${ }^{1,3,4}$ Universitas Negeri Malang \\ ${ }^{2}$ Universitas PGRI Madiun \\ *email: adetrisnawati14@gmail.com
}

Received: 18/12/2017; Revised: 08/01/2018; Accepted: 08/01/2018

\begin{abstract}
Abstrak
Lipstik biasa dimanfaatkan untuk memberikan warna pada bibir, namun kosmetik ini ternyata menyimpan potensi buruk bagi kesehatan manusia. Beberapa lipstik diduga mengandung logam berat yang berbahaya bagi tubuh manusia seperti timbal $(\mathrm{Pb})$, kromium $(\mathrm{Cr})$, dan kadmium $(\mathrm{Cd})$. Semakin gelap warna lipstik, maka kandungan timbalnya disinyalir semakin tinggi. Efek yang ditimbulkan tidak serta merta tampak pada pemakai lipstik karena kandungan logam beratnya, namun jika bahanbahan tersebut terakumulasi dalam tubuh maka pada suatu saat akan menimbulkan efek yang besar karena bersifat toksik dan karsinogen. Pada umumnya kandungan logam berat yang nilainya kecil dalam suatu bahan sukar ditentukan keberadaannya dengan pereaksi-pereaksi kimia, tetapi dapat diketahui jumlah dan keberadaannya dengan spektrofotometri serapan atom. Logam berat yang akan dianalisis adalah logam timbal $(\mathrm{Pb})$, kromium $(\mathrm{Cr})$, dan kadmium $(\mathrm{Cd})$. Data diperoleh dengan cara mencatat hasil uji menggunakan alat spektrofotometer serapan atom kemudian dianalisis dengan menggunakan uji-T.
\end{abstract}

Kata kunci: Lisptik, Timbal, Kromium, Kadmium, Spektroskopi Serapan Atom

\begin{abstract}
Lipstick commonly used to give color to the lips, but lipstick holds the potential of this type of cosmetic is bad for human health. Some lipstick suspected contain heavy metals that are harmful to the human body such as lead, chromium, and cadmium. The darker the color of lipstick, the higher content of lead. The effects are not necessarily appear on consumer because of the heavy metal content, but if these materials accumulate in the body at a time will give rise to great effect because toxic and carcinogen. In general, the heavy metal content of little value in is difficult to determined by the presence of chemical reagents, but can measuring with atomic absorption spectophotometric . Heavy metals to be analyzed is the kind of heavy metal lead $(\mathrm{Pb})$, chromium $(\mathrm{Cr})$ and Cadmium $(\mathrm{Cd})$. Data obtained by noting the results of the test using atomic absorption spectrophotometer then analyzed using T-test.
\end{abstract}

Keywords: Lipstick, Lead, Chromium, Cadmium, Atomic Absorption Spectroscopy

\section{PENDAHULUAN}

Setiap wanita ingin tampil cantik dengan berbagai upaya yang dapat diusahakannya. Salah satu upaya yang dilakukan adalah dengan menggunakan kosmetik. Lipstik merupakan bagian dari kosmetik yang digunakan oleh wanita, terbuat dari lilin, pigmen, minyak, dan sebagainya. Lipstik biasa dimanfaatkan untuk memberikan warna pada bibir. Lipstik merupakan perangkat wajib bagi sebagian perempuan dan merasa penampilannya kurang lengkap jika belum memoleskan lipstik pada bibir. Hal tersebut menyebabkan tidak sedikit pula di antaranya memilih jenis lipstik tahan lama 
demi penampilan yang sempurna. Meski terbilang praktis karena tahan lama digunakan, namun dibalik tahan lamanya lipstik yang digunakan di bibir sebenarnya mengandung zat-zat yang berbahaya bagi tubuh.

\section{Journal of Hazardous Material} tahun 2010 mengungkapkan beberapa lipstik mengandung logam berat yang berbahaya bagi tubuh manusia seperti paraben, methacrylate, timbal, kromium, dan cadmium (Setyanti, 2012). Berdasarkan hasil investigasi dari Badan Pengawas Obat dan Makanan (BPOM) persyaratan kosmetik dalam hal ini lipstik adalah kandungan logam-logam beratnya harus negatif. Lipstik yang mengandung logam berat ini akan sangat berbahaya bagi wanita karena penggunaannya pada daerah bibir yang bukan hanya mengakibatkan sensitivitas pada bibir namun juga dapat tertelan karena menempel pada makanan dan masuk ke dalam tubuh manusia yakni masuk pada sistem pencernaan manusia (Supriyadi, 2008).

Logam berat yang masuk ke dalam tubuh ini diduga bersifat toksik dan dapat mengakibatkan karsinogen (penyebab kanker). Menurut Darmono (2001 dalam Hartoyo, 2007) logam bersifat toksik karena logam tersebut terikat dengan ligan dari struktur biologi. Sebagian besar logam menduduki ikatan tersebut dalam beberapa jenis sistem enzim dalam tubuh. Ikatan tersebut mengakibatkan tidak dapat efektifnya enzim yang bersangkutan. Hal inilah penyebab utama dari toksisitas logam. Beberapa logam berat antara lain $\mathrm{Cd}, \mathrm{Cr}, \mathrm{Cu}, \mathrm{Hg}, \mathrm{Ni}, \mathrm{Pb}$, dan $\mathrm{Zn}$. Elememelemen ini disebut logam berat karena merupakan kelompok logam dengan densitas 6 gram $/ \mathrm{cm}^{3}$ (Hartoyo, 2007).

Joko (2003) menyebutkan bahwa jika terdapat kelebihan kromium pada tubuh maka akan berdampak pada kulit, saluran pernafasan, ginjal dan hati. Keracunan kromat ini dapat menimbulkan iritasi pada kulit, terakumulasi dalam hati, dan keracunan sistemik.

Kadmium yang terhirup melalui udara akan mengakibatkan nafas yang pendek, edema paru-paru dan kerusakan membran mukosa. Kadmium juga bisa terakumulasi pada ginjal dan berperan dalam kerusakan tulang. Kadmium diduga mengganggu produksi progesteron dan testosteron sehingga mengganggu sistem reproduksi (Godt et al, 2006).

Salah satu gangguan yang diakibatkan oleh keracunan $\mathrm{Pb}$ dan persenyawaan anorganiknya adalah gangguan pada sistem hematopoetik adalah terhambatnya aktifitas enzim aminolevulinic acid dehydrogenase (ALAD) dalam eritroblas sumsum tulang dan eritrosit pada sintesis heme. Hal ini akan mengakibatkan penurunan kadar ALAD dengan darah dalam peningkatan kadar amino levulinate acid (ALA) dalam serum dan urin (Goldstein \& Kipem, 1994 dalam Ardyanto, 2005).

Efek yang ditimbulkan tidak serta merta tampak pada pemakai lipstik melainkan bahan-bahan tersebut akan terakumulasi dalam tubuh dan pada suatu saat akan menimbulkan efek yang besar. Setyanti (2012) menyebutkan bahwa semakin gelap warna lipstik, maka kandungan timbalnya disinyalir semakin tinggi.

Dalam penelitian ini, kandungan logam dianalisis keberadaannya dengan menggunakan spektrofotometer serapan atom. Pada umumnya kandungan logam berat yang nilainya kecil dalam suatu bahan sukar ditentukan keberadaannya dengan pereaksi-pereaksi kimia, tetapi dapat diketahui jumlah dan keberadaannya 
dengan spektrofotometri serapan atom. Instrumentasi analisis logam berat yang paling peka dan selektif digunakan adalah spektrofotometri serapan atom karena analisis logam dapat dilakukan dalam tataran atom dan sumber sinar yang digunakan adalah lampu yang menghasilkan cahaya spesifik terhadap logam yang dianalisis (sumber sinar/lampu yang digunakan disesuaikan dengan logam yang dianalisis) sehingga didapat hasil yang selektif dan peka (Gunanjar, 1985 dalam Supriyadi, 2008).

\section{METODE PENELITIAN}

Penelitian ini merupakan penelitian eksperimen dengan pendekatan penelitian deskriptif kuantitatif. Penelitian ini dilakukan di Laboratorium kimia Universitas Negeri Malang.

Populasi penelitian adalah semua lipstik yang beredar dipasaran Indonesia. Sampel dalam penelitian ini adalah 30 gram lipstik cerah dan 30 gram lipstik gelap dari berbagai merk lipstik.

Pada penelitian eksperimen ini melibatkan beberapa variabel yaitu variabel bebas, variabel terikat, dan variable kontrol. Variabel bebas yang berupa kecerahan warna lipstik. Sedangkan variabel terikat dalam penelitian ini yaitu banyaknya kandungan timbal, kromium, dan cadmium yang diukur dalam satuan ppm $(\mathrm{mg} / \mathrm{L})$. Variabel kontrol dalam penelitian ini yaitu banyaknya sampel yang diujikan, volume akuades yang digunakan, larutan standar untuk masing-masing bahan pada konsentrasi 0.05 ppm sampai 10 ppm.

Alat yang digunakan dalam penelitian ini antara lain spektrofotometri serapan atom (SSA), neraca analitik, krus porselin, labu ukur, pipet volume, furnace, beaker glass, spatula logam, corong gelas, penjepit krus, kaca arloji, oven, botol kaca, pipet tetes, dan sarung tangan. Bahan yang digunakan meliputi sampel lipstik berbagai merk dengan masing-masing merk yang diuji meliputi lipstik yang berwarna cerah dan liptik yang berwarna gelap, aquades, asam nitrat pekat $\left(\mathrm{HNO}_{3}\right)$, kertas saring, dan larutan standar pada masing-masing logam berat.

Prosedur yang digunakan untuk penelitian ini yaitu penyiapan sampel adalah sebagai berikut:

a. Penyiapan Sampel

-30 gram lipstik dari masing-masing sampel

- Diabukan dalam furnace sampai didapatkan abu berwarna putih sebanyak 1 gram

- 1 gram abu dilarutkan dengan $\mathrm{HNO}_{3}$ dilanjutkan dengan pelarutan pada aquades hingga volumenya tepat 100 $\mathrm{mL}$

b. Penyiapan Larutan Standar

- Dibuat larutan standar untuk masingmasing logam berat pada konsentrasi $0.05 \mathrm{ppm}$ sampai $10 \mathrm{ppm}$

- Dibaca absorbansinya menggunakan spektrofotometer serapan atom.

c. Pengujian Sampel Lipstik

- Lipstik dibaca absorbansinya untuk memperoleh data

Teknik pengumpulan data dilakukan dengan cara mencatat hasil uji menggunakan alat ukur spektrofotometer serapan atom dengan menggunakan lampu katoda yang sesuai dengan logam yang diperiksa. Analisis data dilakukan dengan dua cara yaitu analisis deskriptif dan analisis statitistik. Analisis deskriptif digunakan untuk mendeskripsikan kecerahan warna lipstik berpengaruh terhadap kandungan logam. Teknik analisis data statistik dengan menggunakan uji-t. 
Apabila mendapatkan hasil yang signifikan, maka dapat disimpulkan bahwa kecerahan warna lipstik berpengaruh terhadap kandungan logam. Analisis statistik ini menggunakan uji-t yang dianalisis dengan bantuan SPSS 16.0 for windows yaitu menggunakan Independent Sample t-Test dengan $\alpha=0,05$ untuk membuktikan hipotesis dan sebelum itu dilakukan uji prasyarat analisis yaitu uji normalitas dengan bantuan program SPSS 16 for Windows, yaitu uji KolmogorofSmirnov (uji K-S) dan uji homogenitas dengan menggunakan formula Lavene Statistic dengan bantuan SPSS 16.0 for windows.

\section{HASIL DAN PEMBAHASAN}

Penelitian ini bertujuan untuk memeriksa kandungan logam berat timbal $(\mathrm{Pb})$, kromium $(\mathrm{Cr})$, dan kadmium $(\mathrm{Cd})$ dalam sampel lipstik beserta pengaruh kecerahan warna terhadap banyaknya kandungan logam berat timbal $(\mathrm{Pb})$, kromium (Cr), dan kadmium (Cd) dalam sampel lipstik. Untuk mendapatkan data berupa kandungan logam berat melalui beberapa tahapan kerja meliputi pengabuan sampel lipstik, pelarutan abu lipstik, dan dilanjutkan dengan analisis menggunakan alat spektrofotometer serapan atom. Analisis dengan menggunakan spektrofotometer serapan atom dipilih karena kandungan logam berat yang nilainya kecil dalam suatu bahan sukar ditentukan keberadaannya dengan pereaksi-pereaksi kimia, tetapi dapat diketahui jumlah dan keberadaannya dengan spektrofotometer serapan atom. Berdasarkan penelitian yang telah dilakukan diperoleh data hasil uji kandungan logam berat timbal $(\mathrm{Pb})$, kadmium (Cd), dan kromium (Cr) pada berbagai merk lipstik yang disajikan pada Tabel 1.
Tabel 1. Data Hasil Uji Kandungan Logam Berat pada Lipstik

\begin{tabular}{clrcc}
\hline \multirow{2}{*}{$\begin{array}{c}\text { Merk } \\
\text { Lipstik }\end{array}$} & Warna & \multicolumn{3}{c}{ Konsentrasi } \\
\cline { 3 - 5 } & & Pb & Cd & Cr \\
\hline A & Terang & 1.346 & 0.355 & 0.005 \\
& Gelap & 0.165 & 0.067 & 0.000 \\
B & Terang & 0.236 & 0.038 & 0.057 \\
& Gelap & 0.023 & 0.019 & 0.072 \\
C & Terang & 0.073 & 0.080 & 0.131 \\
& Gelap & 0.027 & 0.085 & 0.111 \\
E & Terang & 0.054 & 0.026 & 0.001 \\
& Gelap & 0.034 & 0.021 & 0.030 \\
F & Terang & 0.162 & 0.060 & 0.016 \\
& Gelap & 0.143 & 0.040 & 0.000 \\
G & Terang & 0.040 & 0.029 & 0.026 \\
& Gelap & 0.023 & 0.028 & 0.023 \\
H & Terang & 0.207 & 0.090 & 0.122 \\
& Gelap & 0.211 & 0.030 & 0.038 \\
I & Terang & 0.035 & 0.031 & 0.021 \\
& Gelap & 0.035 & 0.020 & 0.021 \\
J & Terang & 0.040 & 0.032 & 0.036 \\
& Gelap & 0.039 & 0.040 & 0.001 \\
J & Terang & 0.040 & 0.032 & 0.036 \\
& Gelap & 0.039 & 0.040 & 0.001 \\
K & Terang & 0.172 & 0.026 & 0.054 \\
& Gelap & 0.099 & 0.009 & 0.029 \\
\hline
\end{tabular}

Berdasarkan data tersebut menunjukkan bahwa sebagian besar lipstik mengandung logam berat baik timbal $(\mathrm{Pb})$, kromium (Cr), dan kadmium (Cd). Padahal menurut Palar (1994 dalam Supriyadi, 2008) menyebutkan bahwa persyaratan kosmetik jenis lipstik adalah kandungan logam beratnya harus negatif karena rawan tertelan ke dalam sistem pencernaan. Hal ini berarti dari semua sampel lipstik yang telah diuji coba tidak layak digunakan karena telah tercemar logam berat $\mathrm{Pb}, \mathrm{Cd}$, dan $\mathrm{Cr}$. Sedangkan menurut US FDA (2006 dalam Saleh et al, 2009) disebutkan bahwa US FDA (US Food and Drug Administration) tidak memberikan batasan terhadap cemaran logam berat khususnya timbal yang terkandung dalam lipstik. Namun hasil evaluasi CSC mengasumsikan bahwa lipstik sama dengan permen karena 
keduanya sama-sama dapat tertelan. Batas cemaran timbal dalam permen $0,1 \mathrm{ppm}$. Hal ini menunjukkan bahwa beberapa sampel melebihi ambang batas 0,1 ppm yang berarti bahwa sampel tersebut tidak layak untuk digunakan.

Data yang telah diperoleh dari Tabel 1 ini kemudian dianalisis menggunakan uji statistik yakni dengan menggunakan uji normalitas, setelah diuji dengan uji normalitas kemudian diuji homogenitas dan dilanjutkan dengan uji-t. Dari hasil uji-t pada logam berat $\mathrm{Pb}$ terhitung nilai probabilitas 0,235. Maka keputusan yang diambil adalah tidak ada pengaruh kecerahan warna lipstik terhadap banyaknya logam $\mathrm{Pb}$. Dari hasil uji-t pada logam berat $\mathrm{Cd}$ terhitung nilai probabilitas 0.227. Maka keputusan yang diambil adalah tidak ada pengaruh kecerahan warna lipstik terhadap banyaknya logam Cd. Dari hasil uji pada logam berat $\mathrm{Cr}$ bahwa nilai probabilitas 0.441. Maka keputusan yang diambil adalah tidak ada pengaruh kecerahan warna lipstik terhadap banyaknya logam $\mathrm{Cr}$.

Tidak adanya pengaruh kecerahan warna lipstik terhadap banyaknya logam berat lipstik dimungkinkan karena logam berat yang terdapat pada lipstik cerah dan gelap bukan merupakan campuran yang dengan sengaja digunakan untuk bahan tambahan pada lipstik. Logam berat yang terdapat pada lipstik diduga sebagai cemaran yang masuk ke dalam bahan dasar lipstik. Sebagaimana yang dikemukakan oleh Adepoju et al (2012) logam berat ditemukan secara alami dalam lingkungan dalam batu, tanah, dan air. Oleh karena itu, logam berat tetap muncul dalam bahan baik pigmen dan material lain dalam semua industri termasuk industri kosmetik. Adepoju et al (2012) juga menambahkan bahwa adanya cemaran logam berat pada lipstik diakibatkan karena rendahnya kualitas bahan yang digunakan untuk membuat lipstik serta ketidakpedulian pabrik kosmetik untuk menghilangkan logam berat pada produk akhir dari lipstik yang dihasilkan. Hal ini akan sangat merugikan konsumen meskipun jumlah logam berat ini sedikit tapi jika terakumulasi dalam waktu yang lama dapat membahayakan sistem di dalam tubuh. Selain itu, berdasarkan fakta selama penelitian tidak semua abu lipstik dapat larut dalam pelarut air dan asam nitrat sehingga terbentuk endapan. Hal ini dapat mempengaruhi hasil analisis logam berat pada lipstik, sehingga mengakibatkan tidak adanya pengaruh kecerahan warna lipstik terhadap kandungan logam beratnya.

Efek logam berat memiliki efek negatif misalnya menjadi pemicu biopsies kanker payudara akibat akumulasi kromium, kadmium, dan timbal. Timbal sebagai bahan yang tidak murni dapat mengganggu kecerdasan bahasa dan tingkah laku, keguguran, mengurangi fertilitas pada laki-laki dan perempuan. Perubahan hormonal, tertundanya masa pubertas bagi perempuan. Pada laki-laki perkembangan testis mungkin akan mengalami mudah diserang. Wanita hamil dan anak-anak juga mudah diserang karena timbal dapat melintasi plasenta dan bisa jadi masuk dalam otak janin sehingga dapat mengganggu kecerdasan janin. Oleh karena ditemukannya logam berat dalam lipstik serta efek logam berat yang terdapat dalam lipstik maka perlu adanya pengawasan yang ketat bagi pabrik kosmetik agar kosmetik khususnya lipstik bebas dari logam berat.

\section{KESIMPULAN}

Hasil penelitian menunjukkan bahwa logam berat ditemukan pada 
berbagai sampel lipstik dan beberapa diantaranya melebihi ambang batas cemaran logam berat yakni lebih dari 0,1 ppm. Dari penelitian ini juga dapat simpulkan bahwa tidak ada pengaruh kecerahan warna lipstik terhadap banyaknya kandungan logam berat karena logam berat ini bukan merupakan bahan yang sengaja ditambahkan pada lipstik melainkan bahan yang secara tidak sengaja masuk ke dalam bahan dasar pembuatan lipstik.

\section{SARAN}

Perlu dilakukan uji lebih lanjut untuk beberapa sampel lain lipstik yang diproduksi di dalam negeri dan luar negeri. Hal lain yang perlu diperhatikan untuk pengujian sampel lipstik adalah pada saat preparasi sampel menjadi abu dan pelarut yang baik untuk melarutkan abu secara sempurna.

\section{DAFTAR RUJUKAN}

Adepoju, B., Oguntibeju, Adebisi, R.A., Okpala, N., \& Coker, H.A.B. (2012). Evaluation of the concentration of toxic metals in cosmetic in Nigeria. Academics Journal, 11(97), 16360-16364.

Ardyanto, D. (2005). Deteksi pencemaran timah hitam $(\mathrm{Pb})$ dalam darah masyarakat yang terpanjang timbal (Plumbum). Jurnal Kesehaan Lingkungan, 2(1), 67-76.

Godt, J., Scheidig, F., Siestrup, C.G., Esche, V., Brandenburg, P., Reich, A., \& Groneberg, D.A. (2006). The toxicity of Cadmium and resulting hazards for human health. Journal of Occupational Medicine and Toxicology, 1(22), 1-6.

Hartoyo, M. A. (2007). Analisis kontaminasi Cadmium pada ikan terhadap masyarakat pesisir sungai
Donan Kabupaten Cilacap. Sains Akuatik, 10(2), 96-104.

Joko, T. (2003). Penurunan Kromium (Cr) dalam limbah cair proses penyamakan kulit menggunakan senyawa slkali $\mathrm{Ca}(\mathrm{OH})_{2}, \mathrm{NaOH}$, dan $\mathrm{NaHCO}_{3}$. Jurnal Kesehatan Lingkungan, 2(2), 39-45.

Saleh, Iman, Al Enazi, Sami, \& Shinwari, N. (2009). Assessment of Lead in cosmetics products. Regulatory Toxicology and Pharmacology, 54, 105-113.

Setyanti, C. A. (2012). Hati-hati, lipstik bisa mengganggu kesehatan. (Online). KOMPAS.com. http://female.kompas.com/read/201 2/08/21/17570983/ Hatihati.Lipstik.Bisa.Mengganggu.Kese hatan. Diakses tanggal 1 November 2012.

Supriyadi. (2008). Analisis logam Kadmium, Timbal, dan Krom pada lipstik secara Spektrofotometri Serapan Atom, Jurnal Kimia dan Teknologi, 4(1), 299-305 